\title{
Владивостокская крепость в контексте российской военно-оборонительной политики на Дальнем Востоке (1879-1923 гг.)
}

Вся история основания, строительства и существования Владивостокской крепости, за исключением использования некоторых объектов крепости в советское время $[\mathbf{2 0} ; \mathbf{2 6}]$, укладывается в последние четыре десятилетия существования Российской империи и годы Гражданской войны, последовавшие за ее распадом. К 1917 г. (момент полной остановки строительства) Крепость "Владивосток" являлась самой укрепленной и мощной морской фортовой крепостью. Более того, кроме немаловажных военно-технических характеристик, нельзя упускать из виду психологическое воздействие крепости как таковой. Без фортификации любая земля будет просто территорией, занятой войсками. С крепостью же появляется ощущение не только защищенности, но и постоянства присутствия, сроднения с землей. Лучше всех высказал это понимание один из строителей крепости, военный инженер, генерал-майор А.П. Шошин: "Основной идеей усиления крепости служит девиз: "Русские здесь остаются навсегда""' [15, с. 74].

В данной работе мы постараемся, используя историко-генетический метод исследования, а также социологический и сравнительный подходы, применяемыми в политологии, проанализировать историю Владивостокской крепости как попытку создания системообразующего компонента российской военно-оборонительной политики на Дальнем Востоке, а также выяснить, насколько строительство крепости увязывалось с общей колонизацией и освоением региона, который она была призвана защищать. Хронологически мы ограничимся 80-ми гг. XIX в. - первыми десятилетиями XX в. То есть периодом с момента постройки первых укреплений и до юридической ликвидации крепости.

Под военно-оборонительной политикой мы будем подразумевать меры государства по использованию своего военно-политического потенциала (равно как и всех средств, имеющихся в его распоряжении), направленные на удержание, закрепление и дальнейшее развитие или эксплуатацию исконной, колонизируемой или захваченной территории. Ввиду ограниченности хронологических рамок мы не будем останавливаться на динамике данного термина, а сосредоточимся на приложении данного термина к деятельности последних лет царского и первых лет советского правительств.

Что касается историографии вопроса, то история Владивостокской крепости (идея зарождения, ход строительства, споров о ее назначении, әксплуатации и т.д.) исследована достаточно основательно. $K$ настоящему времени вышло немало работ, посвященных тем или иным вопросам истории Владивостокской крепости. Наиболее изученными вопросами являются технические характеристики крепости и история её строительства $[1 ; 2 ; 3 ; 4 ; 20 ; 21 ; 24]$. В этом плане особенно следует отметить публикацию, посвященную инженерам, возводившим крепость [4].

Во втором номере журнала "Ойкумена. Регионоведческие исследования" за этот год вышла рубрика "Владивостокская крепость в контексте военной истории Дальнего Востока". В рубрике были представлены новые работы дальневосточных историков, посвященные различным аспектам истории Владивостокской крепости, ее укрепления и развития в качестве системообразу-

(C) Караман B. H., 2021

КАРАМАН Вадим Николаевич, канд. ист. наук, заведующй библиотекой Музея истории Дальнего Востока имени В.К. Арсеньева (2. Владивосток). E-mail: bibl-pgom@mail.ru 
ющего компонента российской военно-оборонительной политики на Дальнем Востоке.

Анализ роли Владивостокской крепости в контексте российской военно-оборонительной политики на Дальнем Востоке, пока находится несколько в стороне от внимания исследователей. Хотя нельзя сказать, что этот вопрос вовсе не затрагивался [см.: 2, с. 35-47].

Рассмотрение данного вопроса требует междисциплинарного подхода. Постановка сугубо исторических проблем: кто, как и где работал над постройкой крепости; какие споры возникали в ходе возведения крепости; какие решения были приняты лицами, от которых зависела судьба крепости (эти вопросы исследованы, хоть и не в полной мере, но все же достаточно основательно) - не позволяет прийти к пониманию того, чем являлась Владивостокская крепость для Российской империи и образовавшегося на ее обломках Советского Союза. Для этого необходим инструментарий политологической науки. Социологическая и сравнительная методологии политологии позволяют взглянуть на Владивостокскую крепость как составную часть военно-оборонительной политики на Дальнем Востоке. Здесь мы отметим, что крепость была все же компонентом, т.е. частью, а не основой этой политики, на что никакая крепость не может претендовать в силу ограниченности фрункциональной специфики.

Роль и место Владивостокской крепости были тесно связаны с общей политикой России в отношении сопредельных государств Северо-Восточной Азии. Тут максима Клаузевица о войне как продолжении политики проявила себя во всей своей силе. Действительно, строительство крепости на территории, юридически закрепленной за Российской империей Пекинским договором с Китаем в 1860 г., оказало немалое влияние на дальнейший ход российской политической истории.

В.О. Ключевский вполне справедливо охарактеризовал Россию как страну, которая колонизуется, "расширяясь вместе с государственной ее территорией" [23, с. 50]. Однако любому расширению есть предел. Последнее крупное приращение Российской империи произошло за счет остатков Империи Тимуридов (Бухарский эмират, Хивинское (Хорезмское) и Кокандское ханства) из-за которых, "Россия была на волосок от войны с Англией" [26, c. 186]. Так что, скорее, понимание ограниченности военных возможностей России, чем личные качества Александра III удержали его от дальнейшей экспансии и от участия в военных конфликтах. К 1890 г. Российская империя полностью завершила оформление границ и практически остановилась в своем территориальном росте. Хотя следует отметить, что идеи дальнейшего продвижения России в Азию все еще владели умами значительной части правящего класса [34, с. 134-168].

Не останавливаясь на разборе всего комплекса военных мер по укреплению дальневосточных границ России, отметим только, что в 1865 г. на российском Дальнем Востоке был образован Восточно-Сибирский военный округ. Он включал в себя территории Иркутской и Енисейской губерний, а также Амурской, Забайкальской, Приморской и Якутской областей. Округ был образован в рамках "Положения о военных округах" одновременно с Кавказским, Туркестанским и Оренбургским в ходе военной реформы Александра II [см.: 7; 8; 10]. В 1884 г. обширный Восточно-Сибирский округ был разделён "для удобства управления и соответственно возможным военным операциям на Приамурский и Иркутский военные округа" [19, с. 22].

Военное присутствие на дальневосточных границах значительно усилилось перед русско-японской войной. Официозное издание под редакцией Генерального штаба сообщало: "После всестороннего рассмотрения вопроса, каким из многочисленных нужд дать предпочтение, в первую очередь были поставлены следующие нужды: а) Продолжение усиления нашего положения на Дальнем Востоке. ... Относительно первой нужды необходимо отметить, что за период 1898-1902 гг. войска Приамурского воен. округа, Маньчжурии и Квантуна были усилены, примерно, на 60.000 чел.; войска получили высшую организацию, будучи сведены в три сибирских корпуса; в 1903 г. наши войска на Дальнем Востоке усилены ещё на 38 батальонов. Вообще за время с 1898 по 1903 гг. военным ведомством на усиление нашей военной мощи на Дальнем Востоке и на сосредоточение там самых необходимых военных средств ...сделано больше, нежели за весь период со дня занятия нами Амура" [19, с. 37]. 
Однако, несмотря на данное несколько оправдательно-хвастливое заявление, в том же издании прямо констатировалось, что Дальний Восток укреплялся в военном плане по остаточному принципу, причем в самую последнюю очередь: "...со вступлением на престол Императора Николая II главная масса отпускаемых военному ведомству сумм шла на увеличение наших сил и средств на западной границе; здесь у нас была расположена главная масса полевых войск, здесь строились новые и улучшались старые крепости и проводились дороги. Остающиеся затем суммы военного ведомства делились для расходования на охрану остальных границ приблизительно в такой последовательности: на границы с Турцией и Персией, затем Афганистана с Индией и на конец на Дальний Восток" [19, с. 34].

С 1880-1881 гг. гражданские транспортные функции Сибирский фолотилии к неудовольствию военного ведомства постепенно передавались частным компаниям на Дальнем Востоке [19, с. 36] (таким как Добровольный фрлот и пароходство Г.М. Шевелева). Сама же Сибирская фрлотилия сосредоточилась на военно-транспортных перевозках, проведении гидрографрических и описных экспедиций, а также на охране котиковых и моржовых промыслов [30]. В 1887 г. во Владивостоке были построены судоремонтные мастерские Военного порта, выросшие в дальнейшем в крупнейшее предприятие "Дальзавод". В 1895 г. для обороны линии границы с Китаем и для обслуживания казачьих станиц была создана Амурско-Уссурийская казачья фрлотилия.

Конечно, нельзя утверждать, что российская военно-оборонительная политика была единой на всем протяжении рассматриваемого периода. Однако мы сосредоточим внимание на совпадающих задачах царской и советской военно-оборонительной политики на Дальнем Востоке ${ }^{1}$ как более важных, чем различия, которые носили временный, тактический характер. Тем более что в первые годы своего существования советская власть была более озабочена своим выживанием, чем разработкой долгосрочной военно-оборонительной политики, особенно на Дальнем Востоке, который был закреплен за советским государством только к 1922 г.

Юг Дальнего Востока, кроме огромной протяжённости и малой заселённости, имел одну очень важную особенность: "Наша колонизация имеет вид клина, слабеющего на своем конце и вклинивающегося в исконные земли желтых народов. Этим слабеющим концом является Уссурийский край" [11, c. 101]. Так обозначил положение России (на тот момент уже Советского Союза) на Дальнем Востоке в 1927 г. В.К. Арсеньев в своем докладе Далькрайкому ВКП(б). Эта характеристика еще более соответствовала реалиям 90-х гг. XIX в. Аналогичный доклад В.К. Арсеньев сделал и за год до этого (в 1926 г.) для ПП ОГПУ по ДВК. В этом докладе он подробно описал "болевые точки" Дальнего Востока, оставшиеся от царского правительства и по наследству перешедшие к советской власти (МИДВ. МПК-15433-200)². Закрепление за Российской империей Дальнего Востока требовало не только юридического оформления в виде договоров и трактатов, но и подтверждения того, что Россия не просто намерена, но и может отстаивать свое право на эти земли. Это было понятно как для центрального, так и для местного чиновничества. Однако между пониманием и реальными действиями, направленными на укрепление России на Дальнем Востоке, существовал практически непреодолимый разрыв. Прежде всего, главным препятствием к укреплению границ было не только поверхностное отношение правительства к Дальнему Востоку, но и высокомерно-пренебрежительное отношение к Азии в целом ${ }^{3}$. Причем это пренебрежение было характерно не только для центральных чиновников, для которых Дальний Восток был очередной колонией и по большому счету

1 Специально не останавливаясь на данном вопросе, только отметим, что совпадение царской и советской военно-оборонительной политики на Дальнем Востоке основано, прежде всего, на том, что оба режима были имперскими и решали аналогичные задачи по укреплению своего влияния на Дальнем Востоке.

2 МИДВ - Музей истории Дальнего Востока имени В.К. Арсеньева (с 23 декабря 2019 г., до этого Приморский государственный объединённый музей имени В.К. Арсеньева (ПГОМ).

3 Не углубляясь в историю европоцентризма, характерного для конца XIX века, заметим, что царской России преодолеть его так и не удалось. 
экзотикой, но и для общей массы офицерства и гражданского чиновничества. Хотя изменения в понимании, говоря современным языком, "азиатского вектора развития" происходили, но они были настолько медленны, что говорить о формировании целенаправленной политики на этом направлении до начала $\mathrm{XX}$ в. не приходится, что и отмечал в своих докладах не только В.К. Арсеньев, но и многие другие, писавшие о Дальнем Востоке.

В деле же возникновения Владивостокской крепости решающую роль сыграл П.Ф. Унтербергер. Он со своей немецкой методичностью всеми силами укреплял Дальний Восток и его границы. Одним из самых удачных его военно-стратегических решений по укреплению восточных границ Российской империи было создание Владивостокской крепости [35].

В 1879 г. П.Ф. Унтербергер, на тот момент заведующий инженерной частью Сибирского военного округа, в виду приграничного положения и удаленности Владивостока от ближайшего сосредоточения войск, предложил не только обеспечить Владивосток новейшими артиллерийскими системами, но и "создать укрепления, обеспечивающие круговую оборону города" [1, с. 28; 12, с. 221]. Это решение положило начало процессу создания Владивостокской крепости. То, что крепость необходима, П.Ф. Унтербергер ясно осознавал, как никто другой. Примечателен один эпизод из его биографрии. Переход через Калган и Тяньзинь в Пекин, а оттуда в Японию, где он встретился с Ивао Оямой (на тот момент министром сухопутных войск Японской империи), надолго запомнился П.Ф. Унтербергеру. По воспоминаниям В.К. Арсеньева, И. Ояма, выпускник особой военной школы Сен-Сир, находившийся при прусских войсках во время фрранко-прусской войны и на практике изучивший передовой военный опыт, на вопрос П.Ф. Унтербергера: "Зачем вам становиться на путь милитаризма. Вы знаете, каким бременем этот милитаризм ложится на плечи европейских народов? Зачем вам, островному государству, нужен фрлот и академия? С кем вам воевать? ... ответил: "Как, вы не понимаете? Конечно, с вами" [11, с. 97]. Отстаивая необходимость Владивостокской крепости, У тербергер не забыл этот ответ, который дал ему будущий победитель русской армии при Мукдене, за 23 года до этого понимавший, что война неизбежна и к ней необходимо готовится.

Периодизация строительства Владивостокской крепости укладывается в три периода, связанных с постройкой различных линий обороны крепости.

Первый период продолжался с возведения в 1879 г. первых крепостных сооружений до 30 августа 1889 г., когда Владивосток был уже официально объявлен крепостью [27, с. 207].

Через 10 лет, в 1899 г., началось строительство второй линии обороны крепости, продолжавшееся вплоть до первой русской революции $[\mathbf{1}, \mathbf{c .} 53$ 107]. На ход возведения фортификационных сооружений в этот период оказала сильное стимулирующее влияние русско-японская война 1904-1905 гг. [см.: 5; 9].

Наконец, на 1906-1917 гг. приходится проектирование и возведение третьей (главной) линии обороны крепости.

За все время своего существования крепость не использовалась по прямому назначению на полную мощность, поскольку попыток штурма или захвата крепости не было. Ни Китай во время войны Цинской империи с "Альянсом восьми держав", в который входила и Российская империя, ни Япония во время русско-японской войны не пытались штурмовать Владивосток ${ }^{4}$. Кроме того, за время Гражданской войны и интервенции войска, в руки которых переходил город, ни разу не сталкивались с сопротивлением крепости именно как крепости, используя сооружения которой, можно было бы отстоять город. Противоборствующие стороны, в том числе и интервенты в Гражданскую войну, также не предпринимали попыток использовать крепость для обороны города. В частности, войска народно-революционной армии ДВР с большим напряжением штурмовали наспех сооруженные укрепления Спасска. Владивосток же со своими мощными укреплениями был занят ими практически без сопротивления. Мы не будем здесь останавливаться на вопросе о том, почему попыток штурма крепости не было, - потому ли, что взять ее было серьёзной

4 Обстрел Владивостока в 1904 г. японской эскадрой такой попыткой считать вряд ли возможно. 
проблемой, или потому, что это не входило в планы воюющих сторон, - но просто отметим это как фракт.

До 1907 г., когда Николай II окончательно присоединился к мнению сторонников строительства крепости [2, с. 41], даже сама идея ее возведения и существования вызывала споры [2, с. 39-41]. Далее мы выделим ряд лежавших в основе этих споров проблем.

Военно-технические проблель. На момент начала строительства крепость предполагалось возвести по последнему слову тогдашней фортификационной науки. Однако всякое средство военной политики - продукт "скоропортящийся". С начала XX в., военные технологии развивались ускоренными темпами, и недавно изобретенные фортификационные конструкции, артиллерийские системы и пр. устаревали, не успев выйти из конструкторских бюро. Такое устаревание было характерно и для крепостей [22; 33, c. $147-149]$.

Однако при строительстве это обстоятельство учитывалось. Владивостокская крепость являла собой фрактически переход от собственно крепости, характерной для XIX в., к укрепрайону, характерному уже для века XX с его двумя мировыми войнами.

После русско-японской войны у существования Владивостокской крепости появились принципиальные противники. Самым горячим противником был на то время военный министр А.Ф. Редигер [31, с. 151-152]. Его доводы были вполне резонны. Это и географическое положение крепости, позволявшее отрезать ее от баз снабжения и связи с основными силами, и оторванность Владивостока и Дальнего Востока в целом от остальной России. В практическом же плане А.Ф. Редигер вполне справедливо опасался, что и само строительство затянется по фоинансовым причинам. Он не особо доверял в этом министерству финансов, поочередно возглавляемому С.Ю. Витте [34, с. 143], Э.Д. Плеске и В.Н. Коковцевым [2, с. 191], указывая на значительные суммы, которые на его взгляд не окупятся. Эти возражения против строительства крепости вполне согласуются и с выводами А.А. Свечина, высказанными им в его трудах по военному делу [32, с. 147].

На практике уязвимость крепостей и фортов наглядно проявилась во Второй мировой войне. Как самый классический пример, назовем операцию по захвату бельгийского форта Эбен-Эмаль немецкими десантниками в 1940 г. [см.: 29, с. 499-500, 35, с. 6-8], не говоря уже о "взломах" линии Мажино, "позиции Зигфрида" и пр. Действительно 30 лет строить крепость, что бы через 20 лет она оказалась уязвимой для штурмовых групп, явно нерентабельно и непродуктивно. Опасения Редигера вполне оправдывались еще и тем, что к фринансовым проблемам примешивались и организационно-технические. "Крепость оказалась в самом запущенном виде во всех отношениях; при наших порядках всё это было совершенно естественно, так как у нас давно уже укоренился взгляд на крепости как на складочное место для сбыта туда разного третьесортного материала или полного хлама, личного и технического" [13, с. 262] - писал в своих воспоминаниях А.П. Будберг. Это его нелестное замечание приходится на период строительства второй линии обороны крепости до начала русско-японской войны.

Военно-социальные проблель. Владивосток становился не просто крепостью, но и приморским городом с медленно, но все же растущим гражданским населением, что в случае войны создавало гуманитарную катастроdy $^{5}$. То, что попытка отторжения Владивостока вполне реальна, и в случае военных действий мирное население попадало в своеобразную ловушку, было очевидно, и данная проблема поднималась еще до основания крепости. Так "9 апреля 1878 года в городской думе рассматривался вопрос о пособии семействам, предназначенных к удалению из Владивостока на случай вторжения неприятеля" [27, с. 120]. Во время русско-японской войны как раз и возникла такая необходимость. В январе 1904 г. Г.В. Подставин (на тот момент и.д. директора Восточного института) отправил донесение по вопросу эвакуации из крепости Восточного института военному губернатору Приморской области A.M. Колюбакину и телеграмму командующему войсками Приамурского

5 В начале XX в. на это не обращали особого внимания, за что пришлось заплатить огромными потерями в Первой мировой войне и тяжелейшими потрясениями за ней последовавшими. 
военного округа И.П. Линевичу [17, с. 100-102]. Однако причиной была не столько угроза занятия Владивостока, сколько неудобство фрункционирования самого Восточного института ${ }^{6}$ (студенческое общежитие было занято под госпиталь Красного Креста). По инициативе директора Восточного института Д.М. Позднеева Восточный институт в феврале 1904 г. переехал в Верхнеудинск ${ }^{7}$ и пробыл там до 23 октября 1905 г. [16, с. 39-41].

Военно-политические проблель. После русско-японской войны все социально-экономические и социально-политические вопросы, так и не разрешенные царским правительством, резко обострились ${ }^{8}$. Это не могло не сказаться и на Владивостокской крепости. Так, 31 мая 1907 г. "солдаты 1-й роты [минного батальона - B.K.] потребовали улучшения питания и замены обмундирования. Командование отказалось удовлетворить эти требования" [18, с. 351], что стало одной из причин вооруженного восстания. Почти весь 1907 г. Владивосток был фрактически на осадном положении (формально осадное положение было введено только с осени 1907 г.) Не углубляясь в историю первой русской революции на Дальнем Востоке и участия в ней всех, кто так или иначе имел отношение к Владивостокской крепости, отметим только, что действия военных властей ${ }^{9}$ и в особенности коменданта Владивостокской крепости В.А. Ирмана ${ }^{\mathbf{1 0}}$ (которого Владивостокский комитет РСДРП за репрессии против мирного населения вполне справедливо "назначил" главным палачом горожан [14, с. 190], несмотря на его боевые заслуги при обороне Порт-Артура и усилия по строительству Владивостокской крепости) отнюдь не повышали обороноспособность Владивостокской крепости. Их действия были вполне в духе общеимперской политики, которая загоняла Российскую империю в тупик. Всё это непонимание и нежелание решать насущные вопросы и вылилось через 10 лет в русскую революцию и Гражданскую войну, которая развела бывших строителей, создателей и чинов крепости по разные стороны. Так, в частности, В.А. Ирман вступил в Добровольческую армию, а А.П. Шошин служил в РККА и принимал деятельное участие в создании ее инженерных войск.

В 1908 г. Унтербергер представил план, если не ликвидирующий, то значительно снижающий потери гражданского населения. Этот план предполагал отделить крепость от города [2, с. 43-44]. Однако, несмотря на его энергичные меры, эта идея, не будучи полностью отвергнута, как говорится, была положена в "долгий ящик" [2, с. 43-44].

В результате, если обобщить упомянутые выше замечания А.П. Будберга, крепость практически превращалась из военного объекта в хозяйственный ${ }^{11}$, что, разумеется, резко снижало ее эффрективность, причем не только военную, которую при әнергичном управлении можно было быстро восстановить. Намного более важным являлось то, что падало ее военно-пропагандистское воздействие. Именно это и пытался донести до императорского двора

6 Многие преподаватели, студенты и слушатели в это время находились в действующей армии.

7 С 1934 г. Ула́н-Удว́.

8 В данном случае отметим, что это не столько заезженный штамп советской историографии, сколько простая констатация фокта.

9 См.: Обвинительный акт Приамурского военно-окружного суда по делу об участниках вооруженного восстания 16-17 октября 1907 г. [14, с. 143-172].

10 См.: Рапорт и.д. коменданта Владивостокской крепости ген-майора В.А. Ирмана командующему войсками военного округа П.Ф. Унтербергеру о подавлении восстания 16-17 октября и мерах по предупреждению новых революционных выступлений [14, с. 173-179].

11 В своем докладе "Русское дело на Дальнем Востоке", сделанном в 1912 году для великого князя Александра Михайловича С.Д. Меркулов отмечает, что "95\% прислуги в крепости Владивосток, если не включать в счет этой прислуги денщиков, приходится на долю китайцев" $[28$, c. 40]. То есть практически вся хозяйственная часть крепости не принадлежала к русской армии, на что и обратил внимание С.Д. Меркулов через более чем 30 лет с начала строительства крепости. 
С.Д. Меркулов ${ }^{12}$. Мнение о России как о военной державе в странах Азии в начале XX в. было уже далеко не тем, что в годы подписания Айгуньского договора и Пекинского трактата. "Россия в глазах китайцев ныне - самая слабая, беззащитная страна из соприкасающихся с Китаем народов" [28, с. 24]. Выводы и прогнозы С.Д. Меркулова, предназначенные в 1912 г. для царского правительства, полностью согласуются с выводами В.К. Арсеньева, сделанными в 1926-1927 гг. для советского ${ }^{13}$.

Несмотря на все трудности (финансовые, технические, кадровые и пр.) крепость постепенно превращалась в действительно мощное фортификационное сооружение. Следует отметить, что, хотя даже самая совершенная крепость сама по себе не решала проблемы безопасности дальневосточных границ, она вполне могла стать катализатором для развития приграничного региона. Главным же препятствием на пути превращения крепости в такой катализатор развития было упорное нежелание центральных властей смотреть на Дальний Восток как на территорию России, а не как на колонию. Чиновники, от которых зависело принятие того или иного решения, мыслили в тех же категориях, что и основная масса населения. В бытовом же обиходе в этот период понятия "Сибирь", "Россия", "Дальний Восток" воспринимались как однопорядковые, рядоположенные, а не как образующие политико-географическую иерархию: Россия $\rightarrow$ Сибирь, Дальний Восток ${ }^{14}$.

Оторванность Дальнего Востока от центральной России намечалось преодолеть постройкой Транссибирской магистрали. Эта постройка отвечала военно-стратегическим задачам ${ }^{15}$ в большей степени, чем экономическим, в отличие от Китайской Восточной железной дороги, являвшейся коммерческой авантюрой С.Ю. Витте. Хотя здесь вполне правомерно говорить об авантюристичности всей дальневосточной внешней политики царизма в целом [см.: 34, c. 149-152; 37, с. 429]. Особенно ясно ее показало поражение России в русско-японской войне, выявившее уязвимость КВЖД. Представления о военно-экономической слабости Японии не оправдались. Порт-Артур был потерян, а с ним и перспектива контроля над Маньчжурией. Тем не менее опыт Порт-Артура как крепости все же не пропал даром и был широко использован для укрепления Владивостокской крепости.

Хотя поражение в русско-японской войне и заставило царское правительство смотреть на Азию более реалистично, за постройкой крепости так и не последовали решительные экономические меры по закреплению Дальнего Востока. Считалось, что самой крепости вполне достаточно и нет необходимости увязывать ее сооружение с экономическим освоением региона. В этом отношении политика советской России на Дальнем Востоке, несмотря на, казалось бы, диаметральную идеологическую противоположность царской, оставалась первоначально прежней. Дальний Восток рассматривался только как источник ресурсов, тогда как строительство промышленных гигантов должно было осуществляться в европейской части страны. То, что оборона региона включает в себя и его экономическое развитие, по-прежнему приходилось объяснять и доказывать [35, с. 354-384].

12 Тот самый Спиридон Дионисович Меркулов, который в 1921 г. возглавил Временное Приамурское правительство.

13 Формально великий князь, крайком ВКП(б) и ПП ОГПУ по ДВК, не являлись правительством, а были, так сказать, первыми инстанциями, которые могли довести содержание представленных докладов до центральных властей.

14 Самые яркие иллюстрации такого восприятия можно найти в публицистике и художественной литературе, характеризующих широко бытующие представления данного периода лучше, чем официальные документы. Достаточно упомянуть "Остров Сахалин" А.П. Чехова, где проведена четкая граница между Россией и Сибирью "... едучи из России в Сибирь... Пока ссыльный молод и крепок, то старается убежать возможно подальше, в Сибирь или Россию" [38, c. 35,344$]$.

15

Планы Х.К.Б фон Мольтке Старшего, базировавшиеся на представлении о стратегической важности железных дорог и настойчиво внедрявшиеся им в Германии, не были особым секретом для русского правительства. Впрочем, сами идеи покрытия страны железнодорожной сетью в военных целях, в это время "витали в воздухе". 
Касаясь связи истории железнодорожного строительства на Дальнем Востоке с военно-оборонительной политикой, отметим только, что совместное развитие Транссибирской магистрали и Владивостокской крепости не столько оживило ситуацию на Дальнем Востоке, сколько стало предметом озабоченности и разногласий центральных властей. Так, согласно данным Стенографического отчета Государственной Думы за 1905-1914 гг., в 1909-1914 гг. "доходы государства с Приамурского генерал-губернаторства составляли 15 млн. руб., а расходы на этот край возросли с 55 млн. до 105 млн. руб. в год" [25, c. 307].

Детальный анализ мероприятий в области военного и экономического освоения Дальнего Востока, который должен охватывать взаимосвязанные вопросы вложений в капитальное строительство, динамики развития промышленности, социально-демографических процессов, баланса внешней и внутренней торговли, выходит за рамки предмета данной статьи. Заметим лишь, что военные расходы государства на Дальнем Востоке в рассматриваемый период превалировали над экономическими и социальными. На наш взгляд, это свидетельствует о том, что царское правительство продолжало действовать в регионе в рамках политики колониализма (в марксистском понимании этого термина), и так и не перешло к политике его планомерного соџиально-экономического развития в качестве органической части страны.

До начала первой мировой войны крепость, пусть и падающими темпами, но все же строилась, становясь самым мощным фортификационным сооружением на Дальнем Востоке. С началом войны доставка цемента по железной дороге замедлилась, а с 1917 г. строительство полностью прекратилось. В итоге Владивостокская крепость так и не была "сдана в эксплуатацию под ключ". Тем не менее все построенные объекты образовали не просто вполне годный к обороне фортификационный объект, но выдающуюся по своей мощности оборонительную систему.

Суммируя изложенное, отметим, что строительство Владивостокской крепости было своевременной и необходимой мерой по укреплению дальневосточных границ Российской империи. Однако это строительство имело смысл только вкупе со всеми остальными мерами по освоению Дальнего Востока. В этом плане царское правительство (как, впрочем, и последовавшее за ним советское) оказалось не на высоте понимания своих задач. Оно рассматривало крепость изолированно, только как военный объект, который создавался и существовал сам по себе. При строительстве крепости внимание фокусировалось прежде всего на сугубо технических вопросах, военно-экономические же оставались в небрежении. Соединить военное присутствие с экономическим закреплением региона удалось только частично. Главной помехой этому стал правительственный взгляд на Дальний Восток, как на обычный колониальный регион, который годен только для эксплуатации и нуждается лишь в военно-стратегической защите от соседей.

В результате Владивостокская крепость являлась больше символом русского военного присутствия на Дальнем Востоке, чем реальным фрактором его безопасности. Но именно в этом качестве символа она сделала гораздо больше, чем просто как фортификационное сооружение. Из военного объекта крепость превратилась в маркер российского суверенитета, являющегося неизмеримо более важной ценностью. Действительно, крепость уже самим фрактом своего существования в период строительства не просто концентрировала и приковывала к себе общественное внимание, но и стягивала к себе значительные интеллектуальные силы, став в этом смысле системообразующим элементом военно-оборонительной политики Российской империи на Дальнем Востоке. 


\section{Литература}

1. Авилов Р.С., Аюшин Н.Б., Калинин В.И. Владивостокская крепость: войска, фортификация, события, люди. Часть І. "Назло надменному соседу". 1860-1905 гг. Владивосток: Дальнаука, 2013. 383 с.

2. Авилов Р.С., Аюшин Н.Б., Калинин В.И. Владивостокская крепость: войска, фортификация, события, люди. Часть II. Уроки Порт-Артура. 1906-1917 гг. Владивосток: Дальнаука, 2014. 408 с.

3. Авилов Р.С., Аюшин Н.Б., Калинин В.И. Владивостокская крепость: войска, фортификация, события, люди. Часть III. "Крепость трех измерений". Владивосток: Дальнаука, 2016. 518 с.

4. Авилов Р.С., Аюшин Н.Б., Калинин В.И. Владивостокская крепость: войска, фортификация, события, люди. Часть IV. Инженеры Владивостокской крепости: счастливые люди. Владивосток: Дальнаука, 2015. 378 с.

5. Авилов P.С. "Создать вторую оборонительную линию...". Организация фортификационной обороны на подступах к Хабаровску в годы Русско-японской войны 1904-1905 гг. (Малмыжская позиция) // Актуальные проблемы изучения истории стран АTP в XIX-XXI вв. (выпуск III) - Хабаровск: КГБНУК "ХКМ им. Н.И. Гродекова". 2019. С. $92-115$.

6. Авилов Р.С. "Для охранения границ Южно-Уссурийского края ссормировать..." История создания и службы регулярной кавалерии на Дальнем Востоке России (1869-1914 гг.). Владивосток: Дальнаука, 2011. 181 с.

7. Авилов Р.С. Введение военно-окружной системы в Восточной Сибири и на Дальнем Востоке России // Тихоокеанское время России и мира: культура, история, политика: XIII всерос. науч. конфр. молодых ученых (с международным участием), Владивосток, 18-22 апреля: программа и тезисы. Владивосток: Издательский дом Дальневост. федерал. ун-та, 2012. С. 117-120.

8. Авилов Р.С. Восточный Сибирский военный округ (1864-1884 гг.): страницы истории. // Военно-исторический журнал. 2013. № 12. С. 3-9.

9. Авилов Р.С. Организация крепостной обороны низовьев и устья Амура накануне Русско-японской войны 1895-1904 гг. // Россия и АТР. 2019. № 2. С. 61-74.

10. Авилов Р.С. Создание Приамурского военного округа: внешнеполитический фрактор (1882-1887 гг.) // Гуманитарные исследования в Восточной Сибири и на Дальнем Востоке. 2011. № 3 (15). 2011. С. 48-52.

11. Арсеньев В.К. Доклад Дальневосточному краевому комитету Всесоюзной коммунистической партии (большевиков) // Желтая опасность. Владивосток: Ворон, 1996. C. $93-117$.

12. Аюшин Н.Б., Калинин В.И. Крепость Владивосток. Создание и развитие в 1860-1899 гг. // Русские первопроходщы на Дальнем Востоке в XVII-XIX вв. (Историко-археологические исследования). Владивосток: Дальнаука, 1998. Том. 3. С. 219-236.

13. Будберг А.П. Сибирские Воспоминания. Владивосток: Общество изучения Амурского края - Приморское отделение Русского географического общества, 2017. $434 \mathrm{c}$.

14. Владивосток. Сборник исторических документов (1860-1907 гг.). Владивосток: Приморское книжное издательство, 1960. 220 с.

15. Воробьева В.В. Русские здесь остаются навсегда // Военно-исторический журнал. 2004. № 7. С. 71-76.

16. Дальневосточный государственный университет. История и современность. 1899-1999. Владивосток: Изд-во Дальневост. ун-та, 1999. 704 с.

17. История Дальневосточного государственного университета в документах и материалах. 1899-1939. Владивосток: Дальнаука, 2004. 616 с.

18. История Дальнего Востока ССCР в эпоху феодализма и капитализма (XVII в. - февраль 1917 г.). М.: Наука, 1990. 471 с.

19. История русской армии и фрлота. В 15 т. Т. 13. М.: Изд. Московского Книгоиздательского Тов-ва "Образование", 1913. 156 с.

20. Калинин В.И., Иванов Ю.В., Гаврилкин Н.В., Зайцев Ю.М., Стехов А.В. Ворошиловская батарея. Башни линкора "Полтава" в береговой обороне. Владивосток: Дальнаука, 2011. 320 с.

21. Калинин В.И., Панасенко А.Е., Иванов Ю.В., Щербаков В.Б., Гаврилкин Н.В. Младший брат Русского острова: остров Аскольд и его оборонительные сооружения. Владивосток: Общество изучения Амурского края - Приморское краевое отделение Русского географического общества, 2019. 216 с.

22. Карбышев Д.М. "Линия Мажино и позиция Зигфрида" // Военная мысль. 1939. № 11. C. 126-142.

23. Ключевский В.О. Собрание сочинений в 9 тт. М.: Мысль. Т. 1. 1989.

24. Крепость Россия: Историко-фортификационный сборник. Выпуск 3. Владивосток: Дальнаука, 2008. 352 с.

25. Кутаков Л.Н. Россия и Япония. М.: Наука, 1988. 384 с. 
26. Ленин В.И. О сепаратном мире // В.И. Ленин. Полное собрание сочинений. Т. 30. М.: Политиздат, 1973. С. 184-192.

27. Матвеев Н.П. Краткий исторический очерк г. Владивостока. Владивосток: Уссури, 1990. $304 \mathrm{c.}$

28. Меркулов С.Д. Русское дело на Дальнем Востоке // Желтая опасность. Владивосток: Ворон. 1996. С. 11-89.

29. Ненахов Ю.Ю. Войска спецназначения во второй мировой войне. Мн.: Харвест, М.: АCT, 2000. 736 с.

30. Панисяк И.В. Сибирская фрлотилия - предшественница Тихоокеанского флота. // Военно-исторический журнал. 1999. № 2. С. 91-93.

31. Редигер А.Ф. История моей жизни. Воспоминания военного министра. В 2-х т. Том 1. М.: Канон-пресс; Кучково поле, 1999. 528 с.

32. Свечин А.А. Стратегия. М.: Военный вестник, 1927. 263 с.

33. Свечин А.А. Эволюция военного искусства. Том II. М-Л.: Государственное издательство. Отдел военной литературы, 1928. 620 с.

34. Схиммельпеннинк ван дер Ойе Д. Навстречу Восходящему солнцу. Как имперское мифотворчество привело Россию к войне с Японией. М.: Новое литературное обозрение, 2009. 421 с.

35. У Утербергер П.Ф. Приамурский край. СПб., 1912. 428 с.

36. Федоров А. Штурм с неба // Военная история. [б. г.]. № 9. С. 6-8.

37. Хобсбаум Э. Век Империи. 1875-1914. Ростов-на-Дону: "Феникс", 1999. 512 с.

38. Чехов А.П. Полное собрание сочинений и писем в 30 т. Т. 14-15. М.: Наука. 1987. $929 \mathrm{c}$.

\section{Транслитерация по ГОСТ 7.79-2000 Система Б}

1. Avilov R.S., Ayushin N.B., Kalinin V.I. Vladivostokskaya krepost': vojska, fortifikatsiya, sobytiya, lyudi. CHast' I. "Nazlo nadmennomu sosedu". 1860-1905 gg. Vladivostok: Dal'nauka, 2013. $383 \mathrm{~s}$.

2. Avilov R.S., Ayushin N.B., Kalinin V.I. Vladivostokskaya krepost': vojska, fortifikatsiya, sobytiya, lyudi. CHast' II. Uroki Port-Artura. 1906-1917 gg. Vladivostok: Dal'nauka, 2014. 408 s.

3. Avilov R.S., Ayushin N.B., Kalinin V.I. Vladivostokskaya krepost': vojska, fortifikatsiya, sobytiya, lyudi. CHast' IIII. "Krepost' trekh izmerenij". Vladivostok: Dal'nauka, 2016. $518 \mathrm{~s}$.

4. Avilov R.S., Ayushin N.B., Kalinin V.I. Vladivostokskaya krepost': vojska, fortifikatsiya, sobytiya, lyudi. CHast' IV. Inzhenery Vladivostokskoj kreposti: schastlivye lyudi. Vladivostok: Dal'nauka, 2015. 378 s.

5. Avilov R.S. "Sozdat' vtoruyu oboronitel'nuyu liniyu...". Organizatsiya fortifikatsionnoj oborony na podstupakh k KHabarovsku v gody Russko-yaponskoj vojny 1904-1905 gg. (Malmyzhskaya pozitsiya) // Aktual'nye problemy izucheniya istorii stran ATR v XIXXXI vv. (vypusk III) - KHabarovsk: KGBNUK "KHKM im. N.I. Grodekova". 2019. S. 92115 .

6. Avilov R.S. "Dlya okhraneniya granits YUzhno-Ussurijskogo kraya sformirovat'..." Istoriya sozdaniya i sluzhby regulyarnoj kavalerii na Dal'nem Vostoke Rossii (1869-1914 gg.). Vladivostok: Dal'nauka, 2011. $181 \mathrm{~s}$.

7. Avilov R.S. Vvedenie voenno-okruzhnoj sistemy v Vostochnoj Sibiri i na Dal'nem Vostoke Rossii // Tikhookeanskoe vremya Rossii i mira: kul'tura, istoriya, politika: XIII vseros. nauch. konf. molodykh uchenykh (s mezhdunarodnym uchastiem), Vladivostok, 18-22 aprelya: programma i tezisy. Vladivostok: Izdatel'skij dom Dal'nevost. federal. unta, 2012. S. 117-120.

8. Avilov R.S. Vostochnyj Sibirskij voennyj okrug (1864-1884 gg.): stranitsy istorii. // Voenno-istoricheskij zhurnal. 2013. № 12. S. 3-9.

9. Avilov R.S. Organizatsiya krepostnoj oborony nizov'ev i ust'ya Amura nakanune Russko-yaponskoj vojny 1895-1904 gg. // Rossiya i ATR. 2019. № 2. S. 61-74.

10. Avilov R.S. Sozdanie Priamurskogo voennogo okruga: vneshnepoliticheskij faktor (1882-1887 gg.) // Gumanitarnye issledovaniya v Vostochnoj Sibiri i na Dal'nem Vostoke. 2011. № 3 (15). 2011. S. 48-52.

11. Arsen'ev V.K. Doklad Dal'nevostochnomu kraevomu komitetu Vsesoyuznoj kommunisticheskoj partii (bol'shevikov) // ZHeltaya opasnost'. Vladivostok: Voron, 1996. S. 93-117.

12. Ayushin N.B., Kalinin V.I. Krepost' Vladivostok. Sozdanie i razvitie v 1860-1899 gg. // Russkie pervoprokhodtsy na Dal'nem Vostoke v XVII-XIX vv. (Istoriko-arkheologicheskie issledovaniya). Vladivostok: Dal'nauka, 1998. Tom. 3. S. 219-236.

13. Budberg A.P. Sibirskie Vospominaniya. Vladivostok: Obshhestvo izucheniya Amurskogo kraya - Primorskoe otdelenie Russkogo geograficheskogo obshhestva, 2017. $434 \mathrm{~s}$. 
14. Vladivostok. Sbornik istoricheskikh dokumentov (1860-1907 gg.). Vladivostok: Primorskoe knizhnoe izdatel'stvo, 1960. $220 \mathrm{~s}$.

15. Vorob'eva V.V. Russkie zdes' ostayutsya navsegda // Voenno-istoricheskij zhurnal. 2004. № 7. S. 71-76.

16. Dal'nevostochnyj gosudarstvennyj universitet. Istoriya i sovremennost'. 18991999. Vladivostok: Izd-vo Dal'nevost. un-ta, 1999. $704 \mathrm{~s}$.

17. Istoriya Dal'nevostochnogo gosudarstvennogo universiteta v dokumentakh i materialakh. 1899-1939. Vladivostok: Dal'nauka, 2004. 616 s.

18. Istoriya Dal'nego Vostoka SSSR v ehpokhu feodalizma i kapitalizma (XVII v. - fevral' 1917 g.). M.: Nauka, 1990. $471 \mathrm{~s}$.

19. Istoriya russkoj armii i flota. V 15 t. T. 13. M.: Izd. Moskovskogo Knigoizdatel'skogo Tov-va "Obrazovanie", 1913. $156 \mathrm{~s}$.

20. Kalinin V.I., Ivanov YU.V., Gavrilkin N.V., Zajtsev YU.M., Stekhov A.V. Voroshilovskaya batareya. Bashni linkora "Poltava" v beregovoj oborone. Vladivostok: Dal'nauka, 2011. $320 \mathrm{~s}$.

21. Kalinin V.I., Panasenko A.E., Ivanov YU.V., SHHerbakov V.B., Gavrilkin N.V. Mladshij brat Russkogo ostrova: ostrov Askol'd i ego oboronitel'nye sooruzheniya. Vladivostok: Obshhestvo izucheniya Amurskogo kraya - Primorskoe kraevoe otdelenie Russkogo geograficheskogo obshhestva, 2019.216 s.

22. Karbyshev D.M. "Liniya Mazhino i pozitsiya Zigfrida" // Voennaya mysl'. 1939. № 11. S. $126-142$.

23. Klyuchevskij V.O. Sobranie sochinenij v 9 tt. M.: Mysl'. T. 1. 1989.

24. Krepost' Rossiya: Istoriko-fortifikatsionnyj sbornik. Vypusk 3. Vladivostok: Dal'nauka, 2008. $352 \mathrm{~s}$.

25. Kutakov L.N. Rossiya i YAponiya. M.: Nauka, 1988. 384 s.

26. Lenin V.I. O separatnom mire // V.I. Lenin. Polnoe sobranie sochinenij. T. 30. M.: Politizdat, 1973. S. 184-192.

27. Matveev N.P. Kratkij istoricheskij ocherk g. Vladivostoka. Vladivostok: Ussuri, 1990. $304 \mathrm{~s}$.

28. Merkulov S.D. Russkoe delo na Dal'nem Vostoke // ZHeltaya opasnost'. Vladivostok: Voron. 1996. S. 11-89.

29. Nenakhov YU.YU. Vojska spetsnaznacheniya vo vtoroj mirovoj vojne. Mn.: KHarvest, M.: ACT, 2000. $736 \mathrm{~s}$.

30. Panisyak I.V. Sibirskaya flotiliya - predshestvennitsa Tikhookeanskogo flota. /I Voenno-istoricheskij zhurnal. 1999. № 2. S. 91-93.

31. Rediger A.F. Istoriya moej zhizni. Vospominaniya voennogo ministra. V 2-kh t. Tom 1. M.: Kanon-press; Kuchkovo pole, 1999. $528 \mathrm{~s}$.

32. Svechin A.A. Strategiya. M.: Voennyj vestnik, 1927. 263 s.

33. Svechin A.A. EHvolyutsiya voennogo iskusstva. Tom II. M-L.: Gosudarstvennoe izdatel'stvo. Otdel voennoj literatury, 1928. $620 \mathrm{~s}$.

34. Skhimmel'pennink van der Oje D. Navstrechu Voskhodyashhemu solntsu. Kak imperskoe mifotvorchestvo privelo Rossiyu k vojne s YAponiej. M.: Novoe literaturnoe obozrenie, 2009. $421 \mathrm{~s}$.

35. Unterberger P.F. Priamurskij kraj. SPb., 1912. 428 s.

36. Fedorov A. SHturm s neba // Voennaya istoriya. [b. g.]. № 9. S. 6-8.

37. KHobsbaum EH. Vek Imperii. 1875-1914. Rostov-na-Donu: "Feniks", 1999. $512 \mathrm{~s}$.

38. CHekhov A.P. Polnoe sobranie sochinenij i pisem v 30 t. T. 14-15. M.: Nauka. 1987. $929 \mathrm{~s}$. 
Караман В. Н. Владивостокская крепость в контексте российской военно-оборонительной политики на Дальнем Востоке (1879-1923 гг.).

Статья посвящена Владивостокской крепости. Рассматривается ее роль в российской военно-оборонительной политике на Дальнем Востоке в 1880-е-1920-е гг. Автор дает краткий анализ воздействия Владивостокской крепости от возникновения идеи, строительства и до момента ее упразднения в 1923 г. на процессы, определявшие и влиявшие на военно-оборонительной политику Российской империи на Дальнем Востоке. Роль Владивостокской крепости тесно увязывается с общей колонизацией и освоением региона. Так же рассматриваются вопросы взаимодействия общеимперской динамики развития и освоения с региональной на фоне строительства крупнейшего на Дальнем Востоке фортификационного сооружения, долженствовавшего стать военной доминантой этого региона.

Ключевые слова: Владивостокская крепость, военное дело, Дальний Восток, колониальная политика, международнье отношения, бортифбикация

Karaman V. N. Vladivostok Fortress in the context of Russian militarydefense policy in the Far East (1879-1923).

The article is devoted to the Vladivostok Fortress. It is considered its role in the Russian military-defense policy in the Far East for the 1880s-1920s. The author gives a brief analysis of the impact of the Vladivostok Fortress from the idea of the emergence, construction and until its abolition in 1923 on the processes that determined the Russian Empire informed on the military-defensive policy in the Far East. The role of the Vladivostok Fortress is closely linked to the general colonization and development of the region. It is also considered issues of interaction between the general imperial dynamics of development with a regional one in the background with the large-scale construction of the largest object of the fortification structure, which must become military dominant in the region.

Key words: Vladivostok fortress, military affairs, the Far East, international relations, fortification

Для цитирования: Караман В. Н. Владивостокская крепость в контексте российской военно-оборонительной политики на Дальнем Востоке (1879-1923 гг.) // Ойкумена. Регионоведческие исследования. 2021. №3. С. 90-101. DOI: 10.24866/1998-6785/2021-3/90-101

For citation: Karaman V. N. Vladivostok Fortress in the context of Russian military-defense policy in the Far East (1879-1923) // Ojkumena. Regional researches. 2021. № 3. P. 90-101. DOI: $10.24866 / 1998-6785 / 2021-3 / 90-101$ 